Eduvest - Journal of Universal Studies

Volume 1 Number 12, December 2021

p- ISSN 2775-3735 e-ISSN 2775-3727

\title{
CRIMINAL LIABILITY FOR PLACEMENT ACTORS ILLEGAL FEMALE LABOR
}

Ibrahim Nainggolan

Muhammadiyah University, North Sumatra, Indonesia

E-mail: ibrahimnainggolan@umsu.ac.id

\begin{tabular}{|c|c|}
\hline ARTICLE INFO & ABSTRACT \\
\hline $\begin{array}{l}\text { Received: } \\
\text { November, } 26^{\text {th }} \\
2021 \\
\text { Revised: } \\
\text { December, } 17^{\text {th }} \\
2021 \\
\text { Approved: } \\
\text { December, 19th } \\
2021\end{array}$ & $\begin{array}{l}\text { The distribution of Indonesian workers carried out by } \\
\text { individuals, not by the government or by official private } \\
\text { companies distributing Indonesian workers, still occurs. The } \\
\text { placement of workers in Indonesia abroad needs to be carried } \\
\text { out in an integrated manner between government agencies, } \\
\text { both central and regional and the participation of the } \\
\text { community in a adequate legal products to provide maximum } \\
\text { protection. The state is obliged to guarantee and protect the } \\
\text { human rights of its citizens who work both at home and abroad } \\
\text { based on the principles of equal rights, democracy, justice, } \\
\text { social, gender equality, and anti-discrimination. know the } \\
\text { criminal responsibility for individual perpetrators who } \\
\text { participate in the placement of illegal female workers to } \\
\text { Malaysia. This research is a normative legal research taken } \\
\text { from secondary data in the form of library research. Based on } \\
\text { the results of the study, it is understood that legal } \\
\text { arrangements regarding legal practice have not been able to } \\
\text { explain the doctrine of participating in criminal acts. On the one } \\
\text { hand, participating in doing so is equated with acts together so } \\
\text { that it does not distinguish between participating in committing } \\
\text { as a form of participation and criminal acts in general. The } \\
\text { target of the placement of workers is directed at placing } \\
\text { workers in the right positions according to their expertise, skills, } \\
\text { talents, interests and abilities by taking into account the } \\
\text { dignity, rights, and legal protection. }\end{array}$ \\
\hline KEYWORDS & Criminal Liability, Perpetrators, Female Workers, Illegal \\
\hline (c) (i) (?) & This work is license \\
\hline
\end{tabular}

Ibrahim Nainggolan (2021). Criminal Liability for Placement Actors Illegal Female Labor. Journal Eduvest. 1(12): 1397-1404

How to cite:

E-ISSN:

Published by: https://greenpublisher.id/ 


\section{INTRODUCTION}

The 1945 Constitution of the Republic of Indonesia in particular Article 27 paragraph (2) states that every Indonesian citizen has the right to work and a decent living. Work is a way for humans to get their dignity by working to improve one's welfare even though they must be faced with the reality of limited employment opportunities in this country (Prasetyo, 2014). In this case the State is responsible for work and a decent living for citizens to live (Engkus, 2016). This formulation means that citizens are entitled to constitutional rights.

Work carried out at home and abroad is a working relationship to produce goods or services to meet the needs of the community (PUTRAWAN, 2018). This is contained in Article 2 paragraph (2) of Law no. 13 of 2003 which explains that the workforce is every man or woman who works to meet the needs of life (Sugiyanto, 2018). According to (Asyhadie, SH, \& Rahmawati Kusuma, 2019) the position of workers can essentially be viewed from two aspects, namely from a juridical aspect and from a socio-economic perspective. From a juridical point of view, workers need a decent living, from a socioeconomic point of view, workers need legal protection from the state in the event of arbitrary actions by employers (DJUMIARTI, 2015).

(Ismatullah \& Bambang, 2013) in his book explains that labor law is a regulation of labor relations, both individual and traditional. The law covers issues such as the application of wages, job security, occupational health and safety. Labor law focuses on workers who work in an employer-employer relationship (Mulyadi, 2017).

The legal rules regarding individual perpetrators of Illegal Workers are contained in Article 82 of the Law on the Protection of Indonesian Migrant Workers (PPMI) which states that the threat of imprisonment is a maximum of 10 years and a fine of 15 billion. such as workers who have complete documents and are registered in the social security membership number, have a physically and mentally healthy body. The threat of imprisonment is a maximum of 10 years and a maximum fine of Rp. 15 billion is also given to individuals who place or send migrant workers.

The fact is that Illegal Workers are back in the conversation today in society, which places Indonesian Workers Abroad using individuals and not through the Government. This violates the provisions contained in Law no. 39 of 2004 concerning the Placement and Protection of Indonesian Migrant Workers, this condition cannot be tolerated because it will threaten the protection of workers.

The condition of illegal placement of Indonesian workers is now more widespread and does not follow the rules set by law, which is carried out for individual actors in placing Indonesian workers illegally. The position of women is highly respected in Islam, women should not be treated harshly and burdened with something that is not their responsibility, as explained in Surah an Nisa verse 19 which means "O you who believe, it is not lawful for you to inherit women by force. and do not trouble them because they want to take back some of what you have given them, unless they do a real heinous work. And get along with them properly. Then if you don't like them, (then be patient) because maybe you don't like something, even though Allah has made it a lot of good."

The fact is that women often have to be the backbone of the family so that sometimes women are forced to work out of town or abroad (Nurgina, 2019). Because of this situation, there are opportunities for crimes committed by certain elements to seek personal gain against the perpetrators (Anastasia, 2012). Women are directed to work abroad with tempting promises by individual labor suppliers, so that women are trapped as illegal workers abroad. 
The distribution of Indonesian workers carried out by individuals, not by the Government or by an official Private Indonesian Migrant Worker Distribution Company, is still happening, one of which is contained in Decision No. 2422/Pid.Sus/2017 on behalf of Goodstar Mozes Banik who took individual actions that participating in the illegal placement of female workers in Malaysia on behalf of the victim, Serlin Agustina, by distributing female workers abroad without using the requirements of the applicable laws.

The judge's decision against Goodstar Mozes Banik at the Kupang District Court stated that the defendant Goodstar Mozes Banik was convincing according to law guilty and proven to have committed a criminal act as an individual perpetrator who carried out the Placement of Female Workers in Malaysia. Serlin Agustina, who is known to be a victim of a violation of work placement abroad as stipulated in the indictment of Article 4 of Law No. 39 of 2004 concerning the Placement and Protection of Indonesian Migrant Workers.

(Ida Hanifah, 2018) in her book explains that the problem is the difference between das sein and das sollen. The questions in the problem formulation must be problematic, to answer them must require analysis of the research raised in the title. Therefore, this study aims to analyze how criminal liability is for individual actors who participate in placing illegal female workers.

\section{RESEARCH METHOD}

The method in this study uses a qualitative method, namely where the data obtained in the decision study (research library) on legal materials will be described and linked in such a way that it can be presented in a more systematic form of writing in order to achieve the desired target. Processing of legal materials is carried out deductively, namely drawing conclusions from a concrete problem that is being faced.

\section{RESULT AND DISCUSSION}

\section{Criminal liability for individual perpetrators who participate in placing illegal female workers.}

The application of the teaching of participating in criminal acts in Indonesia is still a problem. This is due to the pattern of relationships in participating in committing criminal acts which is increasingly complex in practice which is not followed by doctrinal development of the teaching of participating in committing crimes, while legal practice does not describe the teachings of participating in committing crimes in a holistic manner. adequate in court decisions so as not to be able to explain the position of the maker in participating in committing a crime.

Thus, legal practice is often unable to explain the doctrine of participating in criminal acts. On the one hand, participating in committing crimes is simply equated with acts together so that it does not distinguish between participating in committing crimes as a form of participation and criminal acts in general. In this context, the purpose of participating is to expand a criminal act that fulfills all elements of the offense, because the joint act of participating still requires determining the quality of the role and position of the maker, while in a convergence offense all those involved in a criminal act are criminals.

the existence of participating in doing which is identified with a joint act is not able to cover the gap from the principle of a criminal act which is only aimed at one criminal act. On the other hand, the court has also not been able to find new breakthroughs in 


\section{Ibrahim Nainggolan}

constructing complex participation so that legal practice is included in the series of unlimited participation. This is due to the understanding of the notion of an act as a physical movement so that joint implementation in participating in committing is still interpreted as the implementation of all parts of the offense element or acts outside the offense element which play a very important role in realizing the offense. thus giving rise to inclusion of participation to reach complex criminal acts.

The formulation of the teaching of participating in the Criminal Code emphasizes the expansion of criminal responsibility so that people who do not fulfill all the formulations of the offense can be punished based on the determination of participation. Therefore, the doctrine of inclusion in the Criminal Code is placed within the framework of the criminal responsibility function which provides guidelines for judges to determine certain circumstances under which the perpetrators are accountable and therefore can be punished. participation and participation because in principle the interpretation is intended to expand the principle of adjudication used by judges as a guide in determining certain circumstances that are responsible for to the perpetrators of the crime.

The formulation of the doctrine of participation and participation does not explain the forms of participation and participation, on the contrary, the formulation only takes over from the formulation of the Criminal Code which regulates that participants can be punished, even though the Criminal Code is built on two contradictory fundamentals. On the one hand, the subjective inclusion theory states that the punishment of the makers (perpetrators, servants, participating actors and advocates) has the same degree based on the subjective intentions of the makers. This theory underlies the regulation of participation and participation in Article 55 of the Criminal Code which penalizes the same participant as the perpetrator.

On the other hand, objective inclusion theory bases different penalties on objective actions that are manifested in inclusion. This building is used in Article 56 of the Criminal Code which punishes the assistant more lightly than the maker. At first glance, it can be seen that the objective inclusion theory is a theory that discusses criminal acts because it is oriented to objective actions, but in principle the objective inclusion theory only makes objective actions as a measure of criminal responsibility (punishment) against the perpetrators of the crime. Therefore, the objective inclusion theory remains centered on criminal liability and is not a theory of criminal acts.

The occurrence of substantive participation does not have to be followed by a procedural process in determining the people involved in participating as suspects, defendants and even convicts, although it must be proven that participation occurred. Thus, the main problem in participating is the existence of certain legal events and the extent to which certain people are involved in these events. A person is only responsible for his own involvement in the event. The intentional participation in the act serves as a measure of criminal imposition of the perpetrators of participating.

Intentional cooperation in participating must be distinguished from participation offenses, because intentional involvement is related to criminal liability issues, while participation is related to offense issues. This gives birth to the consequence that procedurally the imposition of a criminal offense against the perpetrators of participating in committing crimes does not have to wait for the imposition of a criminal offense against the perpetrators of a criminal act first. In other words, the imposition of a crime against a participating actor can be carried out first from the perpetrator of a criminal act as long as it is proven based on the process of investigation and investigation that there was participation in the conduct involving several people, although it does not have to be followed by the determination of the person involved in participating as a suspect.

According to some experts, there are some opinions of criminal law about mistakes 
which are essentially criminal liability, namely:

a. Metzger

Mistakes are all conditions that provide the basis for personal reproach against perpetrators of criminal law (Metzger, 2011).

b. Van Hamel

The error in an offense is the relationship between the mental state of the perpetrator (psychological) and the realization of the elements of the offense due to his actions (Van Hamel, 1911).

\section{c. Pompe}

The nature of being against the law from the outside is a violation of norms committed by mistake (Pompe, 1994). In this case, the act is against the law. Meanwhile, in terms of dealing with the will of the perpetrator, it is a mistake. Errors can be seen from two angles, namely:

1) From the consequences; mistakes are reprehensible.

2) From its essence; Mistakes are things that are unavoidable by acts against the law.

d. Moeljatno

According to (Moeljatno, 2021), a person can be said to have committed a crime at a certain time. The criminal act in question is an act that harms the community so that the result of the act is reproached by the community. Of course the act was deliberately done and the blame is why he did the act, while he understands that the act is detrimental to the community a criminal act, even though it is unintentional, but is negligent of the obligations that society considers ought to be (duly) carried out by it.

With regard to errors of a psychological nature and normative errors, as well as elements of criminal acts and the opinions of experts regarding errors, it can be concluded that errors have several elements:

a. The existence of the ability to be responsible for the perpetrator, in the sense that the soul of the perpetrator is in a healthy and normal condition;

b. There is an inner connection between the perpetrator and his actions, whether intentional or due to negligence;

c. No forgiving excuses can erase mistakes.

Errors and criminal liability, still leave various problems in criminal law. This is not only in the theoretical field, but even further in legal practice. The science of criminal law has long recognized the notion of unlawful nature, guilt, crime, criminal responsibility, and sentencing which in Indonesia has adopted many of the Dutch criminal law which regulates civil law. law system. Criminal liability is very necessary in a criminal law system in relation to the principle of dead dadestrafs reach.

Intentional and negligence are two forms of error in criminal law. The articles in the Criminal Code mostly contain errors in the form of intentional use of various formulations in addition to several criminal acts committed by negligence, for example in the case of traffic accidents as stated in Articles 359 and 360 KUHP.

Deliberation is an act of willing and realizing or knowing in full a person who commits an act intentionally and must realize or know the consequences that will result from his actions. The element of intent only applies to crimes and not to violations. Regarding the meaning of will above, the will can be addressed to:

a. The prohibited act

b. The result is prohibited

c. Circumstances which constitute a criminal element.

Intentions that are only aimed at prohibited actions are called formal intentions, while those aimed at the consequences are material intentions. 


\section{Ibrahim Nainggolan}

Judging from the inner attitude of the perpetrator, there are three patterns of intentionality:

a. Intentional Purpose (Dolus Directus)

The simplest form of intentionality is the act of the perpetrator who is desired and also imagines the consequences of the act. If what is desired and imagined does not exist then he will not do the act.

b. Intentional with Awareness of Certainty

The intentional pattern of knowing certainty is a separate offense. As a result, there are other undesirable consequences that will inevitably occur. The intentional pattern with conscious certainty rests on the consequences.

c. Deliberately Conscious of Possibilities

This intentional pattern of consciously allows the perpetrator to act by wishing/imagining certain consequences, besides that, other consequences are prohibited and are not desired or imagined. Sometimes this mode of intentional awareness of the possibility can also be called conditional intentionality.

The defendant challenged the sense of justice which was taken into consideration by the honorable panel of judges, in making a decision against the defendant. Regarding the abuse of power, even though the defendant is only a minor employee with a customer service position who is tasked with serving the community at the Kupang Immigration Office. The verdict was that the sentence was sentenced to 4 years in prison, if accumulated, the defendant was sentenced to 10 years in prison, and during that sentence was there a sense of justice for the defendant's wife and children, while the victim Sarlin Agustina Djingi had the opportunity to improve the cost of his life by working as a migrant worker in Malaysia.

The defendant as a Class I Immigration officer in Kupang collaborated with Simon Alfred in making passports for Indonesian workers, victim witness Sarlin Agustina Djingi. However, the criminal conviction of the defendant Godstar Mozes Banik was too severe compared to the severity of the crime committed by the defendant, because the matter that Yohanes and Angelin Wijata were able to send the victim's witness as a migrant worker to Malaysia through a public passport, is a matter that cannot be simply delegated to the defendant.

The Court of Cassation rejected the petition for cassation from the defendant Godstar Mozes Banik which stated that the defendant was still legally guilty of committing a crime, so he was sentenced to imprisonment for 1 (one) year 6 (six) months and a fine of Rp. 200,000,000.00 (two hundred million) if the fine is not paid, it will be replaced with imprisonment for 10 (ten) days, stipulating that the defendant remains in custody.

In conclusion, at the Kupang District Court the defendant was clearly found guilty and imprisoned for 6 (six) years, at the Appeals level the decision was still strengthened and on cassation the sentence was reduced because it could be stated that the worker was called an independent TKI, he dispatched himself, and economically, physically and mentally there is no loss from within the victim, the defendant has long worked as a Civil Servant for 30 years at the Kupang City Immigration, therefore the judge eased his sentence on appeal and was sentenced to 1 (one) year 6 (six) months in prison under Article 4 and Article 102.

\section{CONCLUSION}

Based on the results of the discussion, it can be concluded that the legal provisions for the placement and legal protection for TKW who will be placed abroad have not been 
fully implemented. There are still several cases that show that there are attempts to place TKW abroad not through the mechanism as regulated by Law no. 39 of 2004. There are still individual placements of TKW abroad so that in this case the act is considered a criminal act.

The mode of crime committed by individual actors who participate in the placement of illegal female workers includes helping to produce fake documents against these workers and is carried out in an organized and sustainable manner by using various ways to get what they want by avoiding the law. In accordance with the Criminal Code, the modus operandi of the crimes committed includes those who commit, order to do, participate in doing, encourage and help commit.

Criminal responsibility for the violation of the placement of TKI abroad which was decided by the Judges of the Kupang District Court in the case of the criminal act of placing TKI abroad who was accused of violating the provisions of Law no. 39 of 2004, based on the facts revealed at the trial and based on the judge's conviction, the decision handed down by the Panel of Judges was to apply criminal sanctions in Law no. 39 of 2004, because of the element of experimentation in placing TKI abroad as individuals, which is prohibited under the provisions of Article 4 of Law Number 39 of 2004.

\section{REFERENCES}

Anastasia, Agnes. (2012). Pandangan Laki-Laki Terhadap Perempuan yang Bekerja Di SPBU BBM (Studi Kasus SPBU Di Kota Makassar). Skripsi tidak diterbitkan, Universitas Hasanuddin Makassar, Makassar.

Asyhadie, H. Zaeni, SH, M., \& Rahmawati Kusuma, S. H. (2019). Hukum ketenagakerjaan dalam teori dan praktik di Indonesia. Prenada Media.

DJUMIARTI, TITI. (2015). PERENCANAAN DI SEKTOR KETENAGAKERJAAN YANG BERBASIS PENGEMBANGAN KOMPETENSI DALAM MENGHADAPI PERSAINGAN GLOBAL. Program Studi Doktor Administrasi Publik FISIP-UNDIP, 98.

Engkus, Engkus. (2016). Kajian Naskah Akademik Tentang Optimalisasi Penggunaan Tenaga Kerja Dalam Negeri Dan Pengendalian Tenaga Asing Dalam Penyerapan Tenaga Kerja Di Provinsi Jawa Barat. Kajian Naskah Akademik Tentang Optimalisasi Penggunaan Tenaga Kerja Dalam Negeri Dan Pengendalian Tenaga Asing Dalam Penyerapan Tenaga Kerja Di Provinsi Jawa Barat, 1-19.

Ida Hanifah, Dkk. (2018). Pedoman Penulisan Tugas Akhir Mahasiswa. Medan: Pustaka Prima.

Ismatullah, Dedi, \& Bambang, R. Joni. (2013). Hukum Ketenagakerjaan. Pustaka Setia, Bandung.

Metzger, Gillian E. (2011). Embracing administrative common law. Geo. Wash. L. Rev., 80, 1293.

Moeljatno, S. H. (2021). KUHP (Kitab undang-undang hukum pidana). Bumi Aksara.

Mulyadi, Mohammad. (2017). Peran Pemerintah Dalam Mengatasi Pengangguran Dan Kemiskinan Dalam Masyarakat. Kajian, 21(3), 221-236.

Nurgina, Siti. (2019). Pemberdayaan Perempuan melalui PEKKA (Perempuan Kepala Keluarga) dalam meningkatkan Ekonomi Keluarga: Studi Deskriptif di Dinas Pengendalian Penduduk Keluarga Berencana Pemberdayaan Perempuan Perlindungan Anak dan pemberdayaan Masyarkat (KBP3APM) Kota Sukabumi. UIN Sunan Gunung Djati Bandung. 


\section{Ibrahim Nainggolan}

Pompe, Sebastian. (1994). Between crime and custom: Extra-marital sex in modern Indonesian law. Bijdragen Tot de Taal-, Land-En Volkenkunde, (1ste Afl), 110-122.

Prasetyo, Bagus. (2014). Menilik Kesiapan Dunia Ketenagakerjaan Indonesia Menghadapi MEA. Jurnal Rechts Vinding Online, Media Pembinaan Hukum Nasional.

PUTRAWAN, ARIPIN. (2018). TANGGUNG JAWAB PERUSAHAAN YANG MENEMPATKAN PEKERJA MIGRAN INDONESIA UNTUK KEPENTINGAN PERUSAHAAN SENDIRI SEBAGAI PEKERJA MIGRAN INDONESIA DI LUAR NEGERI. Universitas Mataram.

Sugiyanto, Sugiyanto. (2018). ANCAMAN DAN PELUANG KETENAGAKERJAAN DI INDONESIA PADA ERA MASYARAKAT EKONOMI ASEAN (MEA) DALAM PERSPEKTIF HUKUM EKONOMI. Jurnal Ilmiah Hukum Dan Dinamika Masyarakat, 15(1).

Van Hamel, J. A. (1911). International Union of Criminal Law. J. Am. Inst. Crim. L. \& Criminology, 2, 22. 